\title{
АНАЛІЗ СМЕРТНОСТІ НАСЕЛЕННЯ УКРАЇНИ ВНАСЛІДОК НАВМИСНОГО САМОУШКОДЖЕННЯ
}

\author{
${ }^{1}$ ДВНЗ «Ужгородський національний університет», м. Ужгород, Україна

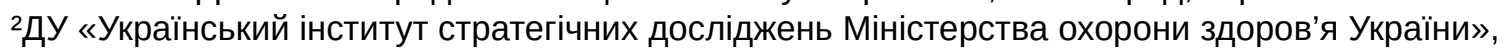 \\ м. Київ, Україна
}

\begin{abstract}
Мета: вивчити і проаналізувати дані про смертність населення в регіональному аспекті внаслідок навмисного самоушкодження за місцем проживання, статтю і способом позбавлення життя.

Матеріали і методи. Під час виконання цього дослідження використано дані Державного комітету статистики України за 2014 р. Методом дослідження є статистичний метод.

Результати. Показники смертності населення внаслідок навмисного самоушкодження в розрахунку на 100000 населення складають серед всього населення України - 18,403, серед міських жителів - 13,621, серед сільських жителів 27,459, серед чоловіків - 31,985, серед жінок - 23,385. Показники мають достовірні відмінності по регіонах країни.

Висновки. Високий рівень смертності населення внаслідок навмисного самоушкодження потребує розробки в рамках системи громадського здоров'я, міжсекторальної програми її профрілактики.
\end{abstract}

КЛЮчОВІ СЛОВА: смертність; навмисне самоушкодження; місце проживання; стать; показники.

Психічне, фрізичне та соціальне здоров'я є важливою складовою життя, які тісно пов'язані між собою та залежать один від одного. Їх взаємозв'язок свідчить, що психічне здоров'я є надзвичайно важливим для загального благополуччя як окремих осіб, так і громад та країни в цілому [8].

Психічні та поведінкові розлади є надзвичайно поширеними і уражають до 25 \% всіх людей в певні періоди їх життя. Відповідно до показника DALI [7], до 2020 р. тягар розладів психіки та поведінки сягне $15 \%$ від усіх хвороб [3].

В Україні показники захворюваності населення на розлади психіки та поведінки є високими $[5,6]$ і при зростанні рівня саморуйнівної поведінки [2], який є одним із найвищих в Європейському регіоні [1], виступають важливою медико-соціальною проблемою.

При цьому навмисне самоушкодження $€$ розповсюдженою причиною смертності населення. Щороку в світі у результаті навмисного самоушкодження помирає понад 800000 людей. Це є другою за частотою причиною смерті у віці від 15 до 29 років [4, 10]. Існують дані, які вказують, що серед дорослого населення на кожного загиблого в результаті навмисного самоушкодження припадає понад 20 осіб, які скоїли суїцидальну спробу [13].

Варто відзначити, що реєстрація самогубств $€$ складною багаторівневою процедурою, яка включає медичні та юридичні аспекти і задіює ряд офріційних державних органів $[9,11,12]$.

Мета роботи: вивчити та проаналізувати дані про смертність населення в регіональному аспекті внаслідок навмисного самоушкодження

(с) Г.О. Слабкий, Н.С. Защик, 2018 за місцем проживання, статтю і способом позбавлення життя.

Матеріали і методи. Під час виконання цього дослідження використано дані Державного комітету статистики України за 2014 р. Методом дослідження є статистичний метод.

Результати дослідження та їх обговорення. На початку дослідження було вивчено та проаналізовано абсолютні дані про спосіб позбавлення життя населенням України залежно від місця проживання (місто, сільська місцевість) та статі (чоловіки, жінки).

Отримані дані наведено в таблиці 1 без урахування тимчасово окупованої території Автономної Республіки Крим і м. Севастополя та частини зони проведення антитерористичної операції.

Аналіз та статистична обробка наведених у таблиці 1 даних вказує на те, що найчастішим способом позбавлення життя $€$ такі навмисні самоушкодження: шляхом повішення, удавлення та задушення - 5963 (88,89 \%), шляхом стрибка з висоти - 175 (2,6 \%), гострим предметом - 156 (2,3 \%), пострілом із гвинтівки, дробовика та великокаліберної вогнепальної зброї - 96 (1,4\%), шляхом занурення у воду та утоплення - $48(0,7 \%)$.

Вивчено показники смертності населення внаслідок навмисного самоушкодження з розрахунку на 100000 населення. Отримані такі дані:

- серед всього населення України - 18,403;

- серед міських жителів - 13,621;

- серед сільських жителів - 27,459;

- серед чоловіків - 31,985;

- серед жінок - 23,385. 
Таблиця 1. Дані про смертність населення України залежно від способу позбавлення життя та місця проживання і статі померлих, 2014 р. (абс.)

\begin{tabular}{|c|c|c|c|c|c|}
\hline \multirow{2}{*}{ Спосіб навмисного самоушкодження } & \multirow{2}{*}{ Всього } & \multicolumn{2}{|c|}{ Місце проживання } & \multicolumn{2}{|c|}{ Стать } \\
\hline & & місто & село & чоловіча & жіноча \\
\hline Всього & 6708 & 3249 & 3459 & 5416 & 1292 \\
\hline $\begin{array}{l}\text { Навмисне самоотруєння та дія ненаркотичних } \\
\text { аналгезивних, жарознижувальних та протиревматичних } \\
\text { лікарських засобів }\end{array}$ & 3 & 2 & 1 & 1 & 2 \\
\hline $\begin{array}{l}\text { Навмисне самоотруєння та дія протисудомних, } \\
\text { седативних, снодійних, протипаркінсонічних та } \\
\text { психотропних засобів, не класифріковані в інших рубриках }\end{array}$ & 10 & 9 & 1 & 4 & 6 \\
\hline $\begin{array}{l}\text { Навмисне самоотруєння і дія наркотиків та } \\
\text { психодислептиків (галюциногенів), не класифріковані в } \\
\text { інших рубриках }\end{array}$ & 2 & 2 & - & 2 & - \\
\hline $\begin{array}{l}\text { Навмисне самоотруєння та дія інших лікарських засобів, } \\
\text { що впливають на вегетативну нервову систему }\end{array}$ & 3 & 3 & - & 2 & 1 \\
\hline $\begin{array}{l}\text { Навмисне самоотруєння і дія інших та неуточнених } \\
\text { лікарських засобів, медикаментів та біологічних } \\
\text { субстанцій }\end{array}$ & 28 & 16 & 12 & 10 & 18 \\
\hline Навмисне самоотруєння та дія алкоголю & 3 & 3 & - & 3 & - \\
\hline $\begin{array}{l}\text { Навмисне самоотруєння і дія органічних розчинників, } \\
\text { галогеновмісних вуглеводнів та їх випарів }\end{array}$ & 2 & 2 & - & 2 & - \\
\hline Навмисне самоотруєння і дія інших газів та випарів & 7 & 6 & 1 & 6 & 1 \\
\hline Навмисне самоотруєння та дія пестицидів & 13 & 1 & 12 & 8 & 17 \\
\hline $\begin{array}{l}\text { Навмисне самоотруєння і дія інших та неуточнених } \\
\text { хімічних і отруйних речовин }\end{array}$ & 39 & 21 & 18 & 22 & 17 \\
\hline $\begin{array}{l}\text { Навмисне самоушкодження шляхом повішення, } \\
\text { удавлення та задушення }\end{array}$ & 5963 & 2759 & 3204 & 4864 & 1099 \\
\hline $\begin{array}{l}\text { Навмисне самоушкодження шляхом занурення у воду } \\
\text { та утоплення }\end{array}$ & 48 & 21 & 27 & 18 & 30 \\
\hline $\begin{array}{l}\text { Навмисне самоушкодження пострілом із ручної } \\
\text { вогнепальної зброї }\end{array}$ & 37 & 24 & 13 & 36 & 1 \\
\hline $\begin{array}{l}\text { Навмисне самоушкодження пострілом із гвинтівки, } \\
\text { дробовика та великокаліберної вогнепальної зброї }\end{array}$ & 96 & 43 & 53 & 94 & 2 \\
\hline $\begin{array}{l}\text { Навмисне самоушкодження пострілом з іншої та } \\
\text { неуточненої вогнепальної зброї }\end{array}$ & 39 & 25 & 14 & 38 & 1 \\
\hline $\begin{array}{l}\text { Навмисне самоушкодження шляхом використання } \\
\text { вибухових речовин та підривних пристроїв }\end{array}$ & 3 & 3 & - & 3 & - \\
\hline Навмисне самоушкодження від диму, вогню та полум'я & 30 & 16 & 14 & 17 & 30 \\
\hline $\begin{array}{l}\text { Навмисне самоушкодження парою, гарячими випарами } \\
\text { та предметами }\end{array}$ & - & - & - & - & - \\
\hline Навмисне самоушкодження гострим предметом & 156 & 101 & 55 & 134 & 22 \\
\hline Навмисне самоушкодження тупим предметом & 2 & 2 & - & 2 & - \\
\hline Навмисне самоушкодження шляхом стрибка з висоти & 175 & 158 & 17 & 111 & 64 \\
\hline $\begin{array}{l}\text { Навмисне самоушкодження кидком під об'єкт, що } \\
\text { рухається, або лежачи на шляху його руху }\end{array}$ & 16 & 10 & 6 & 10 & 6 \\
\hline $\begin{array}{l}\text { Навмисне самоушкодження шляхом аварії моторного } \\
\text { транспортного засобу }\end{array}$ & 4 & 4 & - & 3 & 1 \\
\hline $\begin{array}{l}\text { Навмисне самоушкодження іншими уточненими } \\
\text { засобами }\end{array}$ & 22 & 13 & 9 & 20 & 2 \\
\hline Навмисне самоушкодження неуточненими засобами & 7 & 5 & 2 & 6 & 1 \\
\hline
\end{tabular}

Отримані дані вказують, що рівень смертності населення в результаті навмисного самоушкодження в 2,02 раза вищий серед сільського населення, ніж міського, та серед чоловіків у 1,37 раза вищий, ніж серед жінок.
Вивчено дані про смертність населення 3 визначенням місця та статі в результаті навмисного самоушкодження по регіонах. Отримані дані наведено в таблиці 2. 
Аналіз наведених у таблиці 2 даних вказує на достовірні відмінності по регіонах України як у кількості померлих осіб внаслідок навмисного самоушкодження, так і в співвідношенні померлих залежно від місця проживання (місто, сільська місцевість) та статі (чоловіки, жінки).

Таблиця 2. Дані про смертність населення України по регіонах залежно від місця проживання і статі померлих, 2014 р. (абс.)

\begin{tabular}{|l|c|c|c|c|c|}
\hline \multirow{2}{*}{ Регіон } & \multirow{2}{*}{ Всього } & \multicolumn{2}{c|}{ Місце проживання } & \multicolumn{2}{c|}{ Стать } \\
\cline { 3 - 6 } & & місто & село & чоловіча & жіноча \\
\hline Вінницька & 383 & 102 & 281 & 306 & 77 \\
\hline Волинська & 157 & 56 & 101 & 132 & 25 \\
\hline Дніпропетровська & 749 & 552 & 197 & 594 & 155 \\
\hline Житомирська & 273 & 119 & 154 & 238 & 35 \\
\hline Закарпатська & 167 & 43 & 124 & 129 & 38 \\
\hline Запорізька & 455 & 297 & 158 & 362 & 93 \\
\hline Івано-Франківська & 174 & 61 & 113 & 144 & 30 \\
\hline Київська & 357 & 152 & 205 & 290 & 67 \\
\hline Кіровоградська & 290 & 132 & 158 & 230 & 60 \\
\hline Львівська & 170 & 75 & 95 & 149 & 21 \\
\hline Миколаївська & 299 & 159 & 140 & 242 & 57 \\
\hline Одеська & 583 & 295 & 288 & 478 & 105 \\
\hline Полтавська & 380 & 181 & 199 & 301 & 79 \\
\hline Рівненська & 156 & 46 & 110 & 134 & 22 \\
\hline Сумська & 316 & 155 & 161 & 248 & 68 \\
\hline Тернопільська & 116 & 29 & 87 & 98 & 18 \\
\hline Харківська & 254 & 128 & 126 & 204 & 50 \\
\hline Херсонська & 305 & 154 & 151 & 238 & 67 \\
\hline Хмельницька & 288 & 88 & 200 & 233 & 55 \\
\hline Черкаська & 323 & 131 & 192 & 253 & 70 \\
\hline Чернігівська & 266 & 115 & 151 & 226 & 40 \\
\hline Чернівецька & 104 & 36 & 68 & 80 & 24 \\
\hline м. Київ & & 143 & - & 107 & 36 \\
\hline
\end{tabular}

\section{Висновки}

Поглиблений аналіз смертності населення України внаслідок навмисного самоушкодження вказав, що рівень цього показника з розрахунку на 100000 населення складає серед всього населення України - 18,403, серед міських жителів 13,621, серед сільських жителів - 27,459, серед чоловіків - 31,985, серед жінок - 23,385. Встановлено, що рівень смертності населення в результаті навмисного самоушкодження в 2,02 раза вищий серед сільського населення, ніж міського, та серед чоловіків у 1,37 раза вищий, ніж серед жінок. Показники мають достовірні відмінності по регіонах країни.

Високий рівень смертності населення внаслідок навмисного самоушкодження потребує розробки в рамках системи громадського здоров'я, міжсекторальної програми її профрілактики.

Перспективи подальших досліджень пов'язані з вивченням вікової характеристики загиблих внаслідок навмисного самоушкодження.

\section{Список літератури}

1. Европейская база данных «Здоровье для всех» [Электронный ресурс]. - Копенгаген : Европейское региональное бюро ВОЗ, 2014. - Режим доступа : http://data.euro.who.int/hfadb/shell_ru.html.

2. Загородній С. М. Характеристика саморуйнівної поведінки населення України / С. М. Загородній, В. М. Якимець // Україна. Здоров'я нації. - 2010. - № 2. - С. 35-39.

3. Здоровье и системы здравоохранения: [доклад о состоянии здравоохранения в Европе, 2009 г.]. - Женева : ВОЗ, 2009. - 178 c.

4. Комплексный план действий в области психического здоровья на 2013-2020 гг. Женева : Всемирная организация здравоохранения [Электронный документ], 2013. - Режим доступа : (http://apps.who.int/gb/ebwha/pdf_files/WHA66/ A66_R8-ru.pdf?ua=1 (по состоянию на 20 августа 2014 г.). - Название с экрана.

5. Кульчицька Т. К. Особливості стану здоров'я різних груп населення / Т. К. Кульчицька, Н. О. Кульчицька, Г. В. Лізунова // Матеріали Х з'їзду ВУЛт. - К., 2009. - С. 316-317.

6. Мировая статистика здравоохранения, 2009 г. - Женева : ВОЗ, 2009. - С. 100-104. 
7. Нуллер Ю. Л. Структура психических расстройств / Ю. Л. Нуллер. - К., 2008. - 139 с.

8. Юрьев Е. Системы психиатрической помощи: возможные модели управления и реформирования / Е. Юрьев // Вестник ассоциации психиатров Украины. - 2003. - № 1-2. - С. 124-138.

9. Forty years of increasing suicide mortality in Poland: undercounting amidst a hanging epidemic? / P. I. Hofer, I. R. Rockett, P. Varnik [et al.] // BMC Public Health. - 2012. - Vol. 11 (12). - P. 644.

10. Preventing suicide: a global imperative. Geneva: World Health Organization; 2014. http://www.euro.who.int/ PubRequest?language=Russian.

11. Massive increase in injury deaths of undetermined intent in ex USSR Baltic and Slavic countries: Hidden suicides? I P. Varnik, M. Sisask, A. Varnik [et al.] // Scand. J. Public Health. - 2010. - Vol. 38 (4). - P. 395-403.

12. Validity of suicide statistics in Europe in relation to undetermined deaths: developing the 2-20 benchmark / P. Varnik, M. Sisask, A. Varnik [et al.] // Inj. Prev. - 2012. - Vol. 18 (5). - P. 321-325.

13. WHO mortality database documentation: 1 May 2013 update. Geneva: World Health Organization; 2013 (http://www. who.int/ healthinfo/statistics/mortality_rawdata/en/, accessed 19 May 2014).

\section{References}

1. Yevropeyskaya baza dannykh "Zdorovye dlya vsyekh" [European Health for All database]. (2014). Copenhagen, WHO European regional bureau - Copenhagen, WHO Regional Office for Europe - Retrieved from: http://data.euro.who.int/ hfadb/shell_ru.html. [in Russian].

2. Zahorodniy, S.M. \& Yakymets V.M. (2010). Kharakterystyka samoruinivnoi povedinky naselennia Ukrainy [Characteristic of self-destructive behavior of the population of Ukraine] Ukraina. Zdorovia natsii - Ukraine. The Health of the Nation, 2, 35-39 [in Ukrainian].

3. Zdorovye i sistemy zdravookhraneniya: [doklad o sostoyanii zdravookhraneniya $v$ Yevrope, 2009] [Health and health systems: [State of health report in Europe, 2009]. (2009). Geneva: WHO [in Russian].

4. (2013). Kompleksnyy plan deystviy v oblasti psihikheskogo zdorovya na 2013-2020 [Comprehensive Mental Health Action Plan for 2013-2020]. Geneva: WHO. - Retrieved from: (http://apps.who.int/gb/ebwha/pdf_files/WHA66/A66_R8-ru. pdf?ua=1, for August 20, 2014) [in Russian].

5. Kulchytska, T.K., Kulchytska, N.O., \& Lizunova, H.V. (2009). Osoblyvosti stanu zdorovia riznykh hrup naselennia [Peculiarities of the health of different groups of the population]. Materialy $X$ zizdu VULT - Materials of the X Congress of VULT. Kyiv [in Ukrainian].

6. (2009). Mirovaya statistika zdravookhraneniya, 2009 [World health statistics, 2009]. Geneva: WHO [in Russian].

7. Nuller, Yu.L. (2008). Struktura psikhicheskikh rasstroystv [Structure of mental disorders]. Kyiv [in Russian].

8. Yuriev, Ye. (2003). Sistemy psihiatricheskoy pomoshchi: vozmozhnyye modeli upravleniya i reformirovaniya [Systems of psychiatric care: possible models of management and reforming]. Vestn. Assotsiatsii psikhiatrov Ukrainy - Journal of Association of Psychiatrists of Ukraine, 1-2, 124-138 [in Russian].

9. Hofer, P.I., Rockett, I.R., Varnik, P., Etzersdorfer, E., \& Kapusta, N.D. (2012). Forty years of increasing suicide mortality in Poland: undercounting amidst a hanging epidemic? BMC Public Health., 11 (12), 644.

10. Preventing suicide: a global imperative. (2014). Geneva: World Health Organization. - Retrieved from: http://www.euro. who.int/PubRequest?language=Russian.

11. Varnik, P., Sisask, M., Varnik, A., Yur'Yev, A., Kolves, K., \& Leppik, L. (2010). Massive increase in injury deaths of undetermined intent in ex USSR Baltic and Slavic countries: Hidden suicides? Scand J. Public Health, 38 (4), $395-403$.

12. Varnik, P., Sisask, M., Varnik, A., Arensman, E., Van Audenhove, C., \& van der Feltz-Cornelis, C.M. (2012). Validity of suicide statistics in Europe in relation to undetermined deaths: developing the 2-20 benchmark. Inj. Prev., 18 (5), $321-325$. 13. (2013). WHO mortality database documentation: 1 May 2013 update. Geneva: World Health Organization. - Retrieved from: (http://www.who.int/ healthinfo/statistics/mortality_rawdata/en/, accessed 19 May 2014).

\section{АНАЛИЗ СМЕРТНОСТИ НАСЕЛЕНИЯ УКРАИНЫ ВСЛЕДСТВИЕ УМЫШЛЕННОГО САМОПОВРЕЖ- ДЕНИЯ}

Г.А. Слабкий, Н.С. Защик²

1ГВУЗ «Ужгородский национальный университет», г. Ужгород, Украина

2ГУ «Украинский институт стратегических исследований Министерства здравоохранения Украины», г. Киев, Украина

Цель: выучить и проанализировать данные о смертности населения в региональном аспекте вследствие умышленного самоповреждения по месту жительства, статью и способом лишения жизни.

Материалы и методы. Во время выполнения данного исследования были использованы данные Государственного комитета статистики Украины за 2014 г. Методом исследования стал статистический метод.

Результаты. Показатели смертности населения вследствие умышленного самоповреждения в расчете на 100000 населения складывают среди всего населения Украины - 18,403, среди городских жителей - 13,621, среди сельских жителей - 27,459, среди мужчин - 31,985, среди женщин - 23,385. Показатели имеют достоверные отличия по регионах страны.

Выводы. Высокий уровень смертности населения вследствие умышленного самоповреждения требует разработки в рамках системы общественного здоровья, межсекторальной программы и ее профилактики.

КЛЮЧЕВЫЕ СЛОВА: смертность; умышленное самоповреждение; местожительство; пол; показатели. 
ANALYSIS OF POPULATION MORTALITY RATE IN UKRAINE AS THE RESULT OF DELIBERATE SELF-HARM

G.O. Slabkiy' ${ }^{1}$, N.S. Zashchik ${ }^{2}$

${ }^{1}$ Uzhhorod National University, Uzhhorod, Ukraine

${ }^{2}$ Ukrainian Institute of Strategic Researches MHC of Ukraine, Kyiv, Ukraine

Purpose: to study and analyze the data on population mortality as the result of deliberate self-harm in the place of their residence and sex and the way of the deprivation of life in the regional aspect.

Materials and Methods. The data of the State Committee of Statistics of Ukraine by the year 2014 were used in the course of research. Statistical method was applied in the course of study.

Results. Indices of mortality rate as the result of deliberate self-harm per 100000 of population equals to 18.403 among the total population of Ukraine, to 13.621 among the city dwellers, to 27.459 among rural residents, to 31.985 among men and to 23.385 among women. Indicators have reliable differences in regions of the country.

Conclusions. The high mortality rate as a result of deliberate self-harm among the population requires the development of intersectional program for its prevention within the framework of public health system.

KEY WORDS: mortality; deliberate self-harm; place of residence; sex; indices.

Рукопис надійшов до редакції 03.07.2018 p.

\section{Відомості про авторів:}

Слабкий Геннадій Олексійович - доктор медичних наук, профресор, завідувач кафедри громадського здоров'я ДВНЗ «Ужгородський національний університет».

Защик Наталія Сергіївна - пошукач ДУ «Український інститут стратегічних досліджень Міністерства охорони здоров'я України». 